\title{
Effect of glyphosate application on soil quality and health under natural and zero tillage field conditions
}

\author{
Neli Romano-Armada ${ }^{1,2}$, María J. Amoroso ${ }^{3}$ and Verónica B. Rajal $^{\text {1,2, * }}$ \\ ${ }^{1}$ Instituto de Investigaciones para la Industria Química, CONICET - UNSa, Avenida Bolivia 5150, \\ Salta Capital 4400, Argentina \\ ${ }^{2}$ Facultad de Ingeniería, Universidad Nacional de Salta, Avenida Bolivia 5150, Salta \\ Capital 4400, Argentina \\ ${ }^{3}$ Planta Piloto de Procesos Industriales Microbiológicos, CONICET, Avenida Belgrano y Pasaje Caseros, \\ San Miguel de Tucumán 4000, Argentina
}

\begin{abstract}
Agriculture is a primary source of income in several countries, including Argentina. Among the many agrochemicals used, glyphosate-based herbicides raised controversy, encouraging research to clarify if the benefits of their use outweigh their alleged harmfulness. In this spirit, this study assessed soil quality indicators on glyphosate-sprayed fields under natural (NC) and zero tillage conditions (ZT) in Northwest Argentina, to analyze the effect of the herbicide application on soil degradation. The ZT soils underwent five years of continuous spraying (2-4 times a year) after land clearing, while the NC soil, without any laboring practices, was subjected to two consecutive applications. Among the measured indicators (physical, chemical, and biological), water-stable aggregates (WSA), particulate organic matter (POM) and dehydrogenase activity (DHA) showed quality differences between ZT and NC samples. The highest values were found in NC (WSA 72\%; POM 4.9\%; DHA $1460 \mathrm{mg} \mathrm{TPF/g}$ soild) and the lowest in

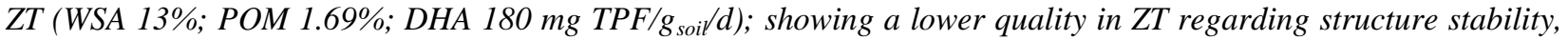
nutrient availability and microbial activity. A Discriminant Analysis revealed that as glyphosate application increased, the overall soil quality decreased within the NC samples, resembling that of ZT. Thus, soil health deterioration was attributed solely to glyphosate spraying in NC. Furthermore, multivariate analysis allowed identification of chemical indicators as of higher sensitivity to the short-term response after application, and biological indicators as more sensitive to long-term changes. The quality decline in time in the NC soil, caused by the use of glyphosate-based herbicides, could endanger the soils sustainability.
\end{abstract}

Keywords: Agriculture, herbicide, indicators, land degradation, soil quality, conservation tillage

\section{Introduction}

In Argentina $14 \%$ of the land area belongs to arable lands, accounting 38 million hectares for agriculture (FAO 2014). Historically the agro-industrial chain has supported much of the Argentine economy, providing the agro-export most of the foreign exchange (Hermans 2003; Ciappa and Gallo 2011).

Agronomic productive systems use many production inputs, among them herbicides based on the chemical compound $\mathrm{N}$-(Phosphonomethyl)glycine $\left(\mathrm{C}_{3} \mathrm{H}_{8} \mathrm{NO}_{5} \mathrm{P}\right)$. Commonly referred as glyphosate, this is a broad spectrum post-emergence herbicide introduced by the company Monsanto in the early seventies (Baird et al. 1971). It interferes the synthesis of phenylalanine, tyrosine, and tryptophan (Dill 2005) by inhibition of the enzyme 5enolpyruvylshikimate-3-phosphate synthase (EPSPS) in the shikimic acid pathway (Amrhein et al. 1980; Steinrücken and Amrhein 1980).
In the last decade, the use of glyphosate raised controversy and currently its environmental and health safety are doubtful. There is evidence of glyphosate toxicity on animal cells even though they lack the enzyme EPSPS (Benachour and Séralini 2009; Poletta et al. 2009; Modesto and Martinez 2010; Paganelli et al. 2010; Clair et al. 2012). Also, economic and ecological aspects of using glyphosate have reached a turning point because the benefits of its use might not outweigh its negative impacts. The improvements in food security and cropping sustainability (Dill 2005; Nail et al. 2007; Lotter 2014) oppose to the need of additional herbicides to control glyphosate-resistant weeds (Nandula et al. 2005; Owen 2008; Powles 2008; Vila-Aiub et al. 2008; Service 2013; Ashworth et al. 2014).

Glyphosate-based herbicides are used in several farming systems, except in organic agriculture (Rigby and Cáceres 2001; Micheni et al. 2014; Mal et al. 2015). In conventional and conservation tillage practices, the soil, even as a non-target compartment, can be exposed to the

\footnotetext{
*Email: vbrajal@gmail.com
} 
herbicide (Givens et al. 2009; Fernandez-Cornejo et al. 2012), especially in zero tillage, which consists of planting the crops without tillage and with the use of herbicides to suppress weeds. Depending on the species to grow, either genetically modified organisms (GMO) to be glyphosateresistant or not, application can occur from one to many times, before sowing, after harvesting, and even with the crop standing (Duke and Powles 2009). This input constitutes a chemical disturbance in the environment for the soil living organisms (Ratcliff et al. 2006; Imfeld and Vuilleumier 2012; Panettieri et al. 2013) and also for the soil itself.

Perturbations of different nature alter the system's dynamic ecological equilibrium and balance, driving it to a new equilibrium if such alteration persists along time (Griffiths et al. 2000; Duke and Powles 2009). Changes can improve or worsen the soil's quality and health, being the first, the capacity of the soil to function productively, under management or natural conditions, supporting human wellbeing (USDA 2002; Janniche et al. 2012), while health is the capacity to sustain its functions over time as a vital living ecosystem (USDA 2015). Thus, assessment of the quality and health of a soil involves the analysis of several physicochemical and biological processes and their interactions through space and time (Rahmanipour et al. 2014).

However, only some properties are measured due to the complexity of the soil matrix and they are commonly grouped as physical, chemical, and biological indicators. To represent the soil's real situation efficiently, they have to be responsive to management and correlate with environmental outcomes (Doran and Parkin 1994; USDA 1996). Many biological indicators of soil quality (MartinezSalgado et al. 2010) complement the pool of physicochemical indicators commonly used to assess soil fertility. Nevertheless, those related to the microbial communities present high sensitivity to environmental changes (Evans and Wallenstein 2014; Lee and Schmidt 2014). The soil microbiota's fast response is due to its participation in redox processes of mineralization and cycling of nutrients. Alterations that might affect the number or activity of native beneficial soil microflora can result in crop and soil damage. Such is the case of alterations in the functional structure and diversity of soil bacteria following the application of glyphosate on genetically modified canola (Lupwayi et al. 2009, 2015).

This study aimed to assess, through an observational study, the effect of glyphosate application on the soil quality and health of fields under natural conditions and zero tillage, in an agricultural region of the Province of Salta in the northwest of Argentina. For that, soil physicochemical properties and microbial activity response from fields with different history of exposure to glyphosate and different cover conditions at farm level on a sandyloam soil were contrasted.

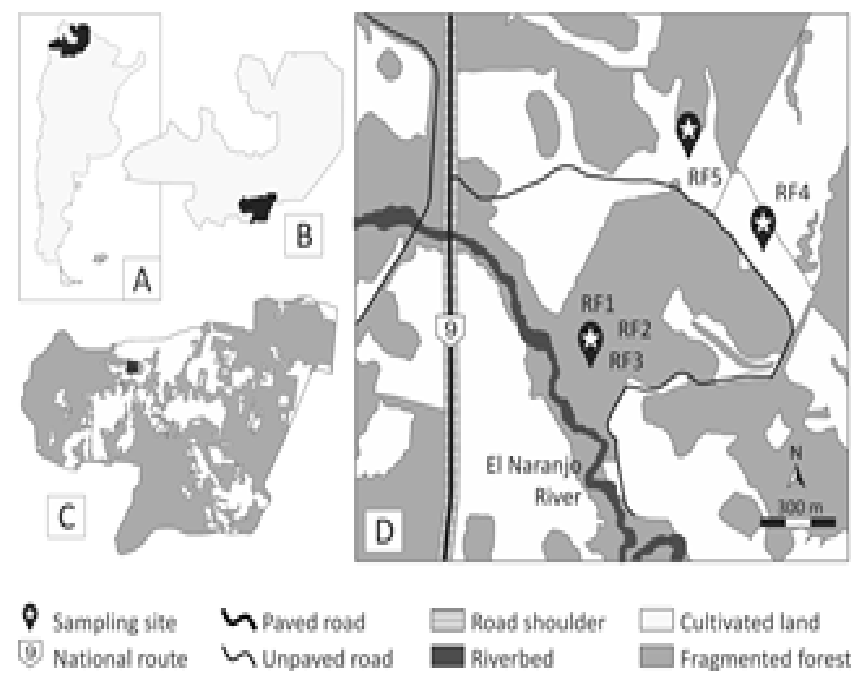

Figure 1: Sampling locations in Northwest Argentina (A) at Salta Province (B) in Rosario de la Frontera Department (C). Detailed in box D, untilled plot with natural cover under a glyphosate-spraying perturbation gradient over time: RF1, natural soil without direct application; RF2, $24 \mathrm{~h}$ after first application (six days after collecting sample RF1); RF3, one month after second event of application (two months after collecting sample RF1); and plots under zero tillage and five years of continuous application: RF4, maize monoculture ( 3 L/ha applied twice at the beginning of the wet season every year); RF5, bean and chickpea sequence $(3 \mathrm{~L} / \mathrm{ha}$ applied four times, as two times at the beginning of each season every year). The commercial herbicide used was a potassium salt formulation of glyphosate, equivalent to 35\% N-(Phosphonomethyl)glycine acid.

\section{Materials and Methods}

\section{Study area and sampling locations}

Soil samples were collected from a commercial farm and not from an experimental field, this was an observational study, and no replicates were collected from each field condition. The farm is located in Rosario de la Frontera, Province of Salta, in the Northwest of Argentina (25 43' 55.58" S; 64 56' 14.01" W, $784 \mathrm{~m}$ a.s.l., Figure 1). The climate is sub-tropical with dry season (April to October), with a mean annual temperature of $19{ }^{\circ} \mathrm{C}$. The average annual maximum and minimum temperatures are $25^{\circ} \mathrm{C}$ and $13{ }^{\circ} \mathrm{C}$, respectively, reaching minimum values of $-5^{\circ} \mathrm{C}$ (July) in the dry season and maximum temperatures of $42{ }^{\circ} \mathrm{C}$ 
(January) during the wet season (November to March). The climate is rather humid (aridity index 0.78), the average annual precipitation is $800 \mathrm{~mm}$, mostly concentrated from December to March (Murphy et al. 2008). According to the classification of the Food and Agriculture Organization of the United Nations, the soil is a Phaeozem, and regarding the United States Department of Agriculture (USDA) Soil Taxonomy, the soil is an Entic Hapludol (INTA 2009). Samples were taken from adjacent fields with different management (Figure 1). For this observational study three plots with different land use, accounting five field conditions (Table 1), were selected to study at farm level the effects of glyphosate use upon soil quality and health.

\section{Soil sampling and physicochemical analyses}

Samples from RF1, RF2, and RF3 were collected from the same plot under different field conditions regarding glyphosate application (Table 1); RF1 and RF2 were taken in October 2010 (dry season), while RF3, RF4, and RF5 were taken in November 2010. Sample collection was done according to standardized guidelines for soil quality assessing ISO 10381-6 (ISO 1993). Briefly, at each field condition five subsamples were collected from a depth of 0 $20 \mathrm{~cm}$ following a zig-zag pattern and were mixed in situ to elaborate a composite-soil sample representative of each field condition, thence they were bagged and tagged on site and transported in ice to the laboratory in a cooler. Once there, samples were air-dried, sieved through a 2 $\mathrm{mm}$ mesh, and then double bagged in black plastic bags (assuring gas exchange) and stored at $4{ }^{\circ} \mathrm{C}$ until further use.

Soil properties for the fertility analysis were carried out by an official laboratory (Soil and Water Laboratory, Instituto Nacional de Tecnología Agropecuaria -INTA-, Cerrillos, Provincia de Salta). The physical indicators determined were: texture as percentage of Sand, Silt and Clay by the Bouyoucos Hydrometer Method (Bouyoucos 1962), water stable aggregates (WSA) by micro sieves method (Corvalán et al. 2000), and available water capacity $(A W C)$ by gravimetry. The chemical indicators determined were: soil electrical conductivity $(S E C)$ by conductimetry in the saturated soil-paste extract, soil $\mathrm{pH}(p H)$ by potentiometry in a distilled water suspension at a 1:2.5 soilto-solution ratio, soil nitrogen $(S N)$ by Kjeldahl method (Bremner 1960), total organic carbon (TOC) by WalkleyBlack method (Walkley and Black 1934), particulate organic matter $(P O M)$ estimated with TOC with van Bemmelen factor (1.724), soil phosphorus availability (SPA) by Bray-Kurtz $\mathrm{N}^{\circ} 1$ method (Bray and Kurtz 1945), calcium $\left(\mathrm{CaCO}_{3}\right)$ and magnesium $\left(\mathrm{MgCO}_{3}\right)$ carbonates (CO3) by sulfuric acid $\left(\mathrm{H}_{2} \mathrm{SO}_{4}\right)$ titration; exchangeable sodium $(E S)$, exchangeable potassium $(E K)$, exchangeable calcium $(E C a)$ and exchangeable magnesium $(E M g)$ by

Table 1. Description of soil samples from fields under different conditions from a commercial farm in Rosario de la Frontera (RF) in the province of Salta, Argentina.

\begin{tabular}{|c|c|c|c|}
\hline Sample & Surface vegetation & $\begin{array}{l}\text { Field condition of agronomic } \\
\text { practices }\end{array}$ & Glyphosate history of application \\
\hline RF1 & $\begin{array}{l}\text { Grassland natural } \\
\text { cover }\end{array}$ & $\begin{array}{l}\text { Natural condition. No previous } \\
\text { laboring practice }\end{array}$ & Without direct application \\
\hline RF2 & $\begin{array}{l}\text { Grassland natural } \\
\text { cover }\end{array}$ & $\begin{array}{l}\text { Natural condition. No previous } \\
\text { laboring practice }\end{array}$ & $\begin{array}{l}\text { Site of sample RF1 } 24 \mathrm{~h} \text { after the first application } \\
\text { of } 3 \mathrm{~L} / \mathrm{ha}^{\mathrm{b}} \text { (six days after RF1 collection) }\end{array}$ \\
\hline RF3 & $\begin{array}{l}\text { Grassland natural } \\
\text { cover }\end{array}$ & $\begin{array}{l}\text { Natural condition. No previous } \\
\text { laboring practice }\end{array}$ & $\begin{array}{l}\text { Site of sample RF } 1 \text {, one month after the second } \\
\text { application of } 3 \mathrm{~L} / \mathrm{ha}^{\mathrm{b}} \text { (two months after } \\
\text { collecting RF } 1 \text { ) }\end{array}$ \\
\hline RF4 & $\begin{array}{l}\text { Corn (Zea mays L.) } \\
\text { monoculture }\end{array}$ & $\begin{array}{l}\text { Five years of zero tillage }{ }^{a} \text { after } \\
\text { land clearing for crops }\end{array}$ & $\begin{array}{l}\text { Five years of continuous application of } 3 \mathrm{~L} / \mathrm{ha}^{\mathrm{b}} \\
\text { twice a year (at pre-plant and preemergence) at } \\
\text { the beginning of the wet season }\end{array}$ \\
\hline RF5 & $\begin{array}{l}\text { Bean (Phaseolus } \\
\text { vulgaris) and } \\
\text { chickpea (Cicer } \\
\text { arietinum L.) crop } \\
\text { sequence }\end{array}$ & $\begin{array}{l}\text { Five years of zero tillage }{ }^{a} \text { after } \\
\text { land clearing for crops }\end{array}$ & $\begin{array}{l}\text { Five years of continuous application of } 3 \mathrm{~L} / \mathrm{ha}^{\mathrm{b}} \\
\text { four times a year. Twice at the beginning of the } \\
\text { dry season in chickpea (at pre-plant and } \\
\text { preemergence) and twice at the beginning of the } \\
\text { wet season for bean (for chemical fallow and at } \\
\text { pre-plant) }\end{array}$ \\
\hline
\end{tabular}


extraction of cations with $1.0 \mathrm{~N}$ ammonium acetate $\mathrm{pH} 7.0$ (Fernández Linares et al. 2006).

Determinations in the soil samples of the concentrations of glyphosate $(P M G)$ and its principal metabolite (Aminomethyl)phosphonic acid (AMPA) were carried out at the Centro de Investigaciones del Medio Ambiente (CIMA, Facultad de Ciencias Exactas, Universidad Nacional de La Plata), following the protocol described by Aparicio et al. (2013).

\section{Determination of biological indicators of soil quality}

Total count of aerobic mesophilic microorganisms (TAM) was determined by plating (Plate Count Agar, Britania) in Petri dishes and incubation $\left(30{ }^{\circ} \mathrm{C}\right.$ for $\left.48 \mathrm{~h}\right)$ of the ten-fold serial dilutions of the soil extracts. For the microbial extraction from the soil matrix, a suspension of $30 \mathrm{~g}$ of soil in $90 \mathrm{~mL}$ of $0.1 \%$ peptone water without chemical dispersing agents was agitated at $250 \mathrm{rpm}$ at $30^{\circ} \mathrm{C}$ for $30 \mathrm{~min}$ in an orbital shaking incubator (Environmental Shaker-Incubator ES-20; Biosan, Riga, Latvia). Then the soil suspension was placed in an ultrasonic bath at $42 \mathrm{kHz}$ (Cole-Parmer Ultrasonic Cleaner, model 8891E-MTH, USA) for $10 \mathrm{~min}$ to disperse microbial aggregates.

Microbial biomass carbon (MBC) was evaluated by Vance's Fumigation-Extraction method (Vance et al. 1987). This method quantifies the microbial biomass in the soil indirectly, by relating it to the amount of carbon released from the cell's cytoplasm when lysed with chloroform. Briefly, tubes with $7.5 \mathrm{~g}$ of soil and $2.5 \mathrm{~mL}$ of distilled water were incubated for $15 \mathrm{~h}$ in the dark at room temperature. Then, only half of the replicates were fumigated with $0.4 \mathrm{~mL}$ of chloroform $\left(\mathrm{CHCl}_{3}\right)$ for $30 \mathrm{~min}$. For the carbon extraction, after addition of $30 \mathrm{~mL}$ of $0.5 \mathrm{M}$ potassium sulfate $\left(\mathrm{K}_{2} \mathrm{SO}_{4}\right)$, the samples were shaken for $1 \mathrm{~h}$ at room temperature (Environmental Shaker-Incubator ES20; Biosan, Riga, Latvia). After centrifuging (C P 36 R, Laboratorios e Industrias Rolco®, Buenos Aires, Argentina) at 2,000 rpm during $15 \mathrm{~min}, 4 \mathrm{~mL}$ of the filtered supernatants were digested with $0.098 \mathrm{~g}$ of potassium dichromate $\left(\mathrm{K}_{2} \mathrm{Cr}_{2} \mathrm{O}_{7}\right)$ and $4 \mathrm{~mL}$ of $98 \% \mathrm{H}_{2} \mathrm{SO}_{4}$ during 15 min at $150{ }^{\circ} \mathrm{C}$ and left to sit at room temperature overnight. Lastly, to measure the optical density at $590 \mathrm{~nm}$ in a spectrophotometer (Genesys 10UV, Spectronic Unicam, Rochester, NY USA) $2 \mathrm{~mL}$ of distilled water were added to the samples and the absorbance was referred to a glucose calibration curve to determine the carbon concentration.

Soil microbial respiration $(M R)$ was determined by incubation of $20 \mathrm{~g}$ of dry soil inside a $400 \mathrm{~mL}$ glass container with a glass vial containing $30 \mathrm{~mL}$ of $0.1 \mathrm{M}$ sodium hydroxide $(\mathrm{NaOH})$ to capture the carbon dioxide
$\left(\mathrm{CO}_{2}\right)$ emitted by microbial respiration. The sealed containers were incubated at $30{ }^{\circ} \mathrm{C}$ for seven days (triplicates for each sample and the control without soil). The soil humidity was adjusted with distilled water to $50 \%$ of its water holding capacity (defined as $A W C$ ). After incubation and before titration with $0.1 \mathrm{M}$ hydrochloric acid ( $\mathrm{HCl}), 0.5 \mathrm{~mL}$ of $20 \%$ barium chloride $\left(\mathrm{BaCl}_{2}\right)$ and drops of phenolphthalein were added to the $\mathrm{NaOH}$ solution.

Dehydrogenase activity (DHA) was determined using a method based on that of Casida et al. (1964). Briefly, a suspension of $0.5 \mathrm{~g}$ of soil in $250 \mu \mathrm{L}$ of distilled water, treated with $0.01 \mathrm{~g}$ of $\mathrm{CaCO}_{3}$ and $100 \mu \mathrm{L}$ of $3 \% 2,3,5-$ triphenyltetrazolium chloride (TTC) solution was mixed and incubated in the dark at $37{ }^{\circ} \mathrm{C}$ for $24 \mathrm{~h}$. After incubation, the addition of $10 \mathrm{~mL}$ of $100 \%$ ethanol $\left(\mathrm{C}_{2} \mathrm{H}_{6} \mathrm{O}\right)$ was followed by $1 \mathrm{~min}$ mixing and filtration through Whatman $\mathrm{N}^{\circ} 5$ paper. The absorbance of the supernatants was measured by spectrophotometry (Genesys 10UV, Spectronic Unicam, Rochester, NY USA) at $485 \mathrm{~nm}$ and referred to a 2,3,5-triphenyl formazan (TPF) calibration curve.

Potentially mineralizable nitrogen $(P M N)$ was determined following Keeney and Bremner's anaerobic incubation method (Keeney and Bremner 1966). Briefly, tubes with $5 \mathrm{~g}$ of soil were flooded with distilled water and sealed without air. After seven days of anaerobic incubation at $40{ }^{\circ} \mathrm{C}$, the content of each tube was mixed with $15 \mathrm{~mL}$ of $4 \mathrm{M}$ potassium chloride $(\mathrm{KCl}), 0.2 \mathrm{~g}$ of magnesium oxide $(\mathrm{MgO})$, and $0.1 \mathrm{~g}$ of De Varda's alloy in distillation tubes. Then, the ammonia recovered in $10 \mathrm{~mL}$ of $2 \%$ boric acid $\left(\mathrm{H}_{3} \mathrm{BO}_{3}\right)$ by distillation (Distilling Unit Kjeltec System 1002 , Tecator, Sweden) was titrated with $0.005 \mathrm{~N} \mathrm{H}_{2} \mathrm{SO}_{4}$. The amount of $P M N$ on the soil was calculated by the difference between the incubated samples and blanks without incubation.

\section{Statistical analyses}

Data analysis was carried out using the statistical package INFOSTAT (Di Rienzo et al. 2014). Data were transformed to make each variable contribute equally to the mean, reducing distortion due to different measurement scales. The transformation performed for the rescaling of each variable was standardization by subtracting the mean to each observation and dividing the result by the standard deviation (Di Rienzo et al. 2014). Pearson coefficients ( $r$ ) with $p<0.05$ were selected to determine correlations, rating their strength as moderate $(0.50$ to 0.74$)$, strong ( 0.75 to $0.89)$, very strong (0.90 to 0.99$)$, and perfect (1). To identify differences between samples regarding biological response, a Kruskal-Wallis one-way analysis of variance was performed with soil quality biological indicators. Then, to establish a similitude pattern between the samples, a 
Hierarchical Cluster Analysis (HCA) was conducted using all variables (Zhao and Ram 2006). Clustering was performed using different distance matrixes for calculation, obtaining the best group arrangement (cophenetic correlation coefficient 0.988) using Gower's similarity measure (S) for distance calculation as $\sqrt{(1-S)}$ (Balzarini et al. 2008).

To assess if glyphosate application affected soil quality indicators and to determine which ones had higher sensitivity, the classification from the HCA was used for a Discriminant Analysis with the K-Nearest Neighbor method (KNN). This analysis is useful for discriminating groups "certain", thus can allocate samples of unknown origin to previously defined groups. Also, it can detect which variables discriminate better the naturally occurring groups allowing reclassification of samples with this specific set of variables, indicating the accuracy of the new allocation as percentages of misclassification or as classification errors if samples allocate in a different group than originally.

Lastly, a Principal Component Analysis (PCA) was performed to describe variability among field conditions. The original correlation matrix was rotated using Varimax rotation and only components with eigenvalues $>1$ were

Table 2. Soil physical and chemical properties of samples from fields with different situations of: vegetal cover, absence or presence of farming practice, and time of exposure to glyphosate-based herbicides application by spraying. RF1: reference soil under natural grassland condition; RF2: grassland 24 h after first application; RF3: grassland one month after second application; RF4: corn monoculture with 5 years of zero tillage and continuous application; RF5: bean-chickpea sequence with 5 years of zero tillage and continuous application.

\begin{tabular}{llllll}
\hline Sample & RF1 & RF2 & RF3 & RF4 & RF5 \\
\hline Texture (Sand : Silt $:$ Clay $)$ & $58: 27: 15$ & $61: 26: 13$ & $58: 30: 12$ & $34: 45: 21$ & $42: 40: 18$ \\
$W S A(\%)$ & 70 & 72 & 57 & 13 & 15 \\
$A W C(\%)$ & 26 & 23 & 23 & 32 & 30 \\
SEC (dS/m) & 0.52 & 0.76 & 0.48 & 0.24 & 0.24 \\
$p H$ & 7.0 & 7.1 & 7.5 & 6.3 & 6.3 \\
$S N(\%)$ & 0.31 & 0.26 & 0.33 & 0.13 & 0.10 \\
$P O M^{\mathrm{a}}(\%)$ & 4.90 & 4.67 & 4.27 & 2.43 & 1.69 \\
$T O C^{\mathrm{a}}(\%)$ & 2.84 & 2.71 & 2.48 & 1.41 & 0.98 \\
$C / N$ & 9 & 10 & 8 & 11 & 10 \\
$S P A(\mathrm{ppm})$ & 32 & 33 & 45 & 6 & 4 \\
$C O 3(\%)$ & 0.6 & 0 & 0 & 0 & 0 \\
$E S P(\%)$ & $\mathrm{ND}^{\mathrm{c}}$ & 0.5 & 0.5 & 0.7 & 0.9 \\
$E K\left(\mathrm{meq} / 100 \mathrm{~g}_{\text {soil }}\right)$ & 0.9 & 0.8 & 0.7 & 1.0 & 0.8 \\
$E C a\left(\mathrm{meq} / 100 \mathrm{~g}_{\text {soil }}\right)$ & $\mathrm{ND}^{\mathrm{c}}$ & 17.0 & 15.9 & 11.5 & 7.8 \\
$E M g\left(\mathrm{meq} / 100 \mathrm{~g}_{\text {soil }}\right)$ & $\mathrm{ND}^{\mathrm{c}}$ & 2.1 & 3.2 & 2.2 & 2.6 \\
$P M G(\mathrm{ppb})$ & 41.99 & 65.34 & $<3^{\mathrm{b}}$ & $<3^{\mathrm{b}}$ & $<3^{\mathrm{b}}$ \\
$A M P A(\mathrm{ppb})$ & 30.7 & 21.4 & 46.6 & 46.4 & 33.2 \\
\hline
\end{tabular}

${ }^{\mathrm{a}}$ Variables also considered biological properties by the USDA soil quality indicators (USDA, 1996).

${ }^{\mathrm{b}}$ Detection limit value used for statistical processing of data.

${ }^{c}$ Not determined, considered as not limiting due to presence of $\mathrm{Ca}^{2+}$ and $\mathrm{Mg}^{2+}$ carbonates.

Physical indicators: Texture: expressed as soil separates percentage; WSA: water stable aggregates; $A W C$ : available water capacity. Chemical indicators: $S E C$ : soil electrical conductivity; $p H$ : soil $\mathrm{pH} ; S N$ : soil nitrogen; POM: particulate organic matter; TOC: total organic carbon; $C / N$ : carbon-nitrogen ratio; SPA: soil phosphorus availability; CO3: calcium and magnesium carbonates; ESP: exchangeable sodium percentage; $E K$ : exchangeable potassium; $E C a$ : exchangeable calcium; $E M g$ : exchangeable magnesium; $P M G$ : N(Phosphonomethyl)glycine soil concentration; AMPA: (Aminomethyl)phosphonic acid soil concentration.

defined a priori based on the variables selected, representing the observations in a space where the differences between the groups are maximal. Also for classifying new cases in the groups established a priori by a classification rule based on independent variables (Balzarini et al. 2008). Briefly, the analysis considers the classification provided by the user to the software as selected for analysis (Kaiser 1960). For the retained factors, the influence of the loadings on each factor was considered negligible $(<0.50)$, moderate $(0.50$ to 0.75$)$, strong $(0.75$ to 0.90$)$ and very strong $(>0.9)$. Nonindependent variables $(C / N, P O M, q C O)$ and incompletedata variables (CO3, ECa, EMg, ESP) were not included in the PCA. 


\section{Results and discussion}

\section{Physicochemical characterization}

A higher proportion on the Silt and Clay separate in RF4 and RF5 (Table 2) indicated heavier texture in these samples than that of samples RF1 to RF3. The texture is a property that does not change significantly under zero tillage. Hence the difference could be attributed to the distance between the sampling sites (Figure 1). According to the observations of Gupta and Larson (1979) and Vargas-Tapia et al. (2008), a very strong correlation between the $A W C$ and the different soil separates evidenced the effect of texture on the soil's water holding capacity. In this case, these soils showed higher $A W C$ when the Sand separate decreased $(r=-0.96)$ and the Silt and Clay proportions rose $(r=0.93$ and 0.99 , respectively).

Regarding the structure of the surface soil $(0-20 \mathrm{~cm}$ depth) analyzed by measuring WSA on microaggregates, natural condition soils (RF1, RF2, RF3) presented higher aggregate stability than those under zero tillage (RF4, RF5) (Table 2). Contrary to the lower stability of microaggregates associated to coarse soils observed by Sheehy et al. (2015), there was a very strong correlation between the WSA and the Sand proportion $(r=0.97)$. Thence a stability reduction occurred in samples RF4 and RF5 when the percentage of finer particles rose (Table 2). Despite the coarser texture of samples RF1 and RF2, a strong correlation between POM and WSA $(\mathrm{r}=0.97)$ indicated that the higher contents of $E C a$ and POM (Table 2) could be responsible for cementing the soil particles (Horn et al. 1994; Paradelo et al. 2013). Differences between the maximum values of WSA (RF1 and RF2) and the lowest (RF4 and RF5) could be attributed to farming since it reduces the soil's $P O M$ content (Mandiola et al. 2011). Nonetheless, even though RF3 was from a natural condition soil, it showed a medium value of WSA, indicating a reduction of soil stability that could be due to a chemical perturbation caused by glyphosate input, for the only difference between RF3 and its pairs RF1 and RF2 was a higher exposure to glyphosate. Thus, samples with less exposure to the glyphosate-based herbicide showed higher structural stability regardless farming practices.

Even though the $E C a$ decrease from samples RF1 to RF5 was evident (Table 2), there was no significant correlation of this variable with any other indicator. Reduction of $\mathrm{Ca}^{2+}$ content could be partly responsible for the decline in the soil aggregates stability (Paradelo et al. 2013). Sample RF5 showed the lowest value of ECa; this could be associated with the plant-cover species difference, as dicots have a higher intake of $\mathrm{Ca}^{2+}$ compared to monocots (Broadley et al. 2003; White and Broadley 2003).
Between $\mathrm{Na}^{+}, \mathrm{K}^{+}, \mathrm{Mg}^{2+}$, and $\mathrm{Ca}^{2+}$ soil content, the latter presented a higher proportion, having a major weight in the cation exchange capacity of these soils. The ECa and POM decline partnered with the $S E C$ decrease, since the latter correlated highly with the cation exchange capacity $(r=0.95)$ and with the organic matter content $(r=0.87)$ of the soil (Table 2).

Lower values of SPA on zero tillage soil samples (RF4, RF5) could be attributed to the repeated extraction of the nutrient by crops over the years in different productive agronomic cycles. The phosphorus provided by the breakdown of the glyphosate-based herbicide applied along with the lack of phosphorus depletion from crop uptake could explain the greater value of SPA determined on sample RF3 (Table 2).

The soil's $P M G$ and $A M P A$ showed a strong inverse correlation $(r=-0.86)$. As expected, due to the short period between herbicide application and sampling $(24 \mathrm{~h})$, the highest value of $P M G$ was determined in sample RF2. Also, $P M G$ was below detection limit (Table 2) in samples RF3, RF4 and RF5 because of the fast dissipation of glyphosate in soil (Andréa $e t$ al. 2003). However, and surprisingly, glyphosate was also detected on sample RF1, where there was no exposure by direct application. This content could be attributed to spray drift from agricultural sprayers used to apply the herbicide in nearby plots (Reddy et al. 2010). However, the larger value of TOC in RF1 could overrule the effects of the glyphosate since carbon is known to be a determining factor for soil quality.

\section{Biological indicators}

Soil microbial activity indicators $D H A$ and $P M N$ showed no significant difference at $p<0.05$ between samples. However at $p<0.10$ the differences between RF5 and RF1-RF2 (Table 3) indicated a higher biological activity on samples RF1 and RF2, both from natural condition soil (and with the shortest history of exposure to glyphosate). Regarding $P M N$, RF5 showed a significantly different value $\left(21 \pm 1 \mu \mathrm{g} \mathrm{N}-\mathrm{NH}_{4} / \mathrm{g}_{\text {soil }}\right)$, approximately four times lower respect to the other samples. The reduced microbial activity could be explained by a lower source of organic nitrogen to be mineralized. Also, the high proportion of fine particles in this sample allows higher micro-pore space, giving physical protection to organic matter against microbial degradation, hindering nitrogen turnover (Rowlings et al. 2012; Li et al. 2015). However, a deficient source of nutrients and organic nitrogen to be mineralized does not completely agree with the values of $S P A, S N$, and texture (Sand, Silt, Clay), similar between RF4 and RF5 (Table 2). In sample RF5 the high proportion of fine particles, low $P O M$ and $E C a$, combined with the soil's compaction and lack of movement caused by zero tillage (Hill 1990; Nunes et al. 2015) may result in less pore connectivity by poor cementing, as evidenced by low WSA 
(Table 2). Lower interconnected pore space between soil aggregates prevents proper air circulation and provision of oxygen for nitrifiers and other microorganisms in general (Doran 1980; Li et al. 2015) as showed by the low value of

Table 3: Biological properties of soil samples from fields with different situations of: vegetal cover, farming absence or presence, and time of exposure to glyphosate-based herbicides application by spraying. RF1: reference soil under natural grassland condition; RF2: grassland $24 \mathrm{~h}$ after first application; RF3: grassland one month after second application; RF4: corn monoculture with 5 years of zero tillage and continuous application; RF5: bean chickpea sequence with 5 years of zero tillage and continuous application.

\begin{tabular}{|c|c|c|c|c|c|c|}
\hline Sample & $\begin{array}{l}T A M^{\mathrm{a}} \\
\left(\mathrm{CFU} / \mathrm{g}_{\text {soil }}\right)\end{array}$ & $\begin{array}{l}M B C^{\mathrm{a}} \\
\left(\mu \mathrm{g} \mathrm{C} / \mathrm{g}_{\text {soil }}\right)\end{array}$ & $\begin{array}{l}M R^{\mathrm{a}} \\
\left(\mu \mathrm{g} \mathrm{C}-\mathrm{CO}_{2} / \mathrm{g}_{\text {soil }}\right)\end{array}$ & $\begin{array}{l}D H A^{\mathrm{a}} \\
\left(\mathrm{mg} \mathrm{TPF} / \mathrm{g}_{\text {soil }} / \mathrm{d}\right)\end{array}$ & $\begin{array}{l}P M N^{\mathrm{a}} \\
\left(\mu \mathrm{g}-\mathrm{NH}_{4} / \mathrm{g}_{\text {soil }}\right)\end{array}$ & $q C O$ \\
\hline RF1 & $1.8 \times 10^{8} \pm 7.8 \times 10^{7} \mathrm{bc}$ & $122 \pm 54 \mathrm{c}$ & $2963 \pm 175 a b c$ & $1445 \pm 20 \mathrm{~b}$ & $87 \pm 12 b$ & 24 \\
\hline RF2 & $2.0 \times 10^{8} \pm 2.1 \times 10^{7} \mathrm{c}$ & $28 \pm 17 \mathrm{ab}$ & $3113 \pm 34 \mathrm{bc}$ & $1460 \pm 34 b$ & $92 \pm 6 b$ & 113 \\
\hline RF3 & $2.8 \times 10^{7} \pm 6.0 \times 10^{6} \mathrm{abc}$ & $55 \pm 5 b c$ & $2723 \pm 82 a b$ & $1196 \pm 125 \mathrm{ab}$ & $86 \pm 6 a b$ & 49 \\
\hline RF4 & $1.9 \times 10^{7} \pm 6.2 \times 10^{6} \mathrm{ab}$ & $21 \pm 4 \mathrm{ab}$ & $3271 \pm 224 \mathrm{c}$ & $219 \pm 4 \mathrm{ab}$ & $80 \pm 9 \mathrm{ab}$ & 156 \\
\hline RF5 & $7.4 \times 10^{6} \pm 5.7 \times 10^{5} \mathrm{a}$ & $16 \pm 1 \mathrm{a}$ & $682 \pm 22 \mathrm{a}$ & $180 \pm 2 \mathrm{a}$ & $21 \pm 1 \mathrm{a}$ & 53 \\
\hline $\mathrm{p}$ value & $0.013^{\mathrm{b}}$ & $0.022^{\mathrm{b}}$ & $0.034^{\mathrm{b}}$ & 0.078 & 0.070 & \\
\hline
\end{tabular}

${ }^{\mathrm{a}}$ Mean \pm Standard deviation. Means followed by the same letter within each column show no significant difference at the informed $p$ value. ${ }^{\mathrm{b}} p$ values $<0.05$.

Biological indicators: TAM: total plate count of aerobic, mesophilic microorganisms; $M B C$ : microbial biomass carbon; $M R$ : microbial respiration; $D H A$ : dehydrogenase activity; $P M N$ : potentially mineralizable nitrogen; $q C O$ : metabolic quotient (MR/MBC)

Table 4: Principal component analysis of selected variables. Columns show the varifactors (VF) of the first three principal components after rotation, and proportion of variance explained by each factor.

\begin{tabular}{|c|c|c|c|c|}
\hline Groups of variables & Variables & VF1 & VF2 & VF3 \\
\hline Physical & Sand $(\%)$ & 0.86 & 0.16 & 0.48 \\
\hline \multirow[t]{4}{*}{ Indicators } & Silt $(\%)$ & -0.80 & -0.21 & -0.56 \\
\hline & Clay $(\%)$ & -0.96 & -0.04 & -0.27 \\
\hline & $A W C(\%)$ & -0.92 & -0.14 & -0.33 \\
\hline & $W S A(\%)$ & 0.74 & 0.39 & 0.54 \\
\hline Chemical & $p H$ & 0.95 & 0.31 & 0.07 \\
\hline \multirow[t]{7}{*}{ Indicators } & $S E C(\mathrm{dS} / \mathrm{m})$ & 0.61 & 0.30 & 0.69 \\
\hline & TOC $(\%)$ & 0.69 & 0.58 & 0.43 \\
\hline & $S N(\%)$ & 0.85 & 0.49 & 0.14 \\
\hline & $S P A(\mathrm{ppm})$ & 0.92 & 0.37 & 0.11 \\
\hline & $E K\left(\mathrm{meq} / 100 \mathrm{~g}_{\text {soil }}\right)$ & -0.81 & 0.57 & 0.11 \\
\hline & $P M G(\mathrm{ppb})$ & 0.22 & 0.29 & 0.93 \\
\hline & $A M P A(\mathrm{ppb})$ & -0.08 & 0.20 & -0.98 \\
\hline Biological & $T A M\left(\mathrm{CFU} / \mathrm{g}_{\text {soil }}\right)$ & 0.27 & 0.40 & 0.87 \\
\hline \multirow[t]{4}{*}{ Indicators } & $M B C\left(\mu \mathrm{g} \mathrm{C} / \mathrm{g}_{\text {soil }}\right)$ & 0.40 & 0.49 & 0.17 \\
\hline & $M R\left(\mu \mathrm{g} \mathrm{C}-\mathrm{CO}_{2} / \mathrm{g}_{\text {soil }}\right)$ & 0.09 & 0.96 & 0.10 \\
\hline & $D H A\left(\mathrm{mg} \mathrm{TPF} / \mathrm{g}_{\text {soil }} / \mathrm{d}\right)$ & 0.75 & 0.43 & 0.50 \\
\hline & $P M N\left(\mu \mathrm{g} \mathrm{N}-\mathrm{NH}_{4} / \mathrm{g}_{\text {soil }}\right)$ & 0.35 & 0.90 & 0.14 \\
\hline \multirow[t]{4}{*}{ Qualitative Variable } & Exposure (months) & -0.83 & -0.40 & -0.39 \\
\hline & Variance $^{\mathrm{a}}$ & 9.32 & 4.05 & 4.75 \\
\hline & Variance proportion $^{\mathrm{b}}(\%)$ & 49.1 & 21.3 & 25.0 \\
\hline & Cumulative proportion (\%) & 49.1 & 70.4 & 95.4 \\
\hline
\end{tabular}

${ }^{\mathrm{a}}$ Explained by rotated component.

${ }^{\mathrm{b}}$ Percent of total variance explained by varifactor.

Sand, Silt and Clay: Textural soil separates proportion; $A W C$ : available water capacity; WSA: water stable aggregates; $p H$ : soil $\mathrm{pH}$; $S E C$ : soil electrical conductivity; TOC: total organic carbon; $S N$ : soil nitrogen; $S P A$ : soil phosphorus availability; $E K$ : exchangeable potassium; PMG: N-(Phosphonomethyl)glycine soil concentration; AMPA: (Aminomethyl)phosphonic acid soil concentration; TAM: total plate count of aerobic, mesophilic microorganisms; $M B C$ : microbial biomass carbon; $M R$ : microbial respiration; DHA: dehydrogenase activity; PMN: potentially mineralizable nitrogen; Exposure: history of soil exposure to glyphosate. 
TAM for RF5 (Table 3). Also, RF4 has a less optimal crop rotation but a history of lower glyphosate application, while RF5 has a more optimal crop rotation but a history of higher glyphosate application. Thus, the crop rotation effect may overrule the glyphosate effect. However, there may be other factors coming from unknown practices over the years in these long-term exposure field conditions (RF4 and RF5), affecting the soil response leading to confounding effects.

Between samples, $M R$ also presented significant differences, having RF5 the lowest value (Table 3). Even though there was no significant difference between RF1 and RF2 in $M R$, different causes explain their high microbial activity. Quantitation of microbial biomass determined by $M B C$ in RF1 was four times greater than that of RF2 (Table 3). Hence, while microbial activity on RF1 could be attributed to a larger amount of microorganisms in a vegetative state, activity on RF2 could be due to a fast response of the microbial community to face the recent glyphosate formulation application (Haney et al. 2000). Both RF2 and RF4 presented the highest values of $q C O$, indicating a stress upon the microbial community due to some perturbation of the system (Anderson and Domsch 2010).

Contrary to what was expected, there was no significant correlation between the microbial quantitation indicators TAM and $M B C(p=0.37)$. Although all samples, but RF3, presented significant differences regarding $T A M$, the values tend to decline from RF1 to RF5. The drop of $M B C$ form RF1 to RF2 (Table 3) could be attributed to the elimination of viable vegetative cells following the glyphosate application, with the liberation of spores to the soil. Thus, the difference of quantitation in RF2 could be given by the fact that $M B C$ accounts for all carbon from culturable and non-culturable vegetative cells, while TAM includes only culturable cells and spores able to form colonies. The lower values of $M B C$ in RF4 and RF5 were consistent with the TAM decline, evidencing lower quality on those samples.

All the biological quality indicators showed an intermediate value in sample RF3 (Table 3). This fact could be interpreted either as a step in the middle of the recovery of the soil returning to its prior state; or as a stage towards a new equilibrium of the soil's microbiota adjusting to the new environmental ruling conditions to reach a new climax community. In either case, neither hypothesis can be accepted or ruled out completely in the absence of other samples which could allow establishing the direction of the change.

\section{Multivariate analysis}

Briefly, the data was processed with three statistical analyses to identify changes in the soil properties as a response to the spraying with glyphosate for weed control.
First, the clustering analysis showed an arrangement of samples that grouped soils according to the absence or presence of farming practices. Within these pre-established clusters, when samples were classified by a discriminating analysis using different sets of indicators, natural condition soils with varying levels of glyphosate application showed misclassification. This indicated that some of their properties resembled those of soils under zero tillage and with lower quality. Lastly, the principal components analysis allowed identifying more closely the variables driving the soil samples classification.

\section{Hierarchical clustering analysis (HCA) and k- nearest neighbor discriminant analysis (KNN)}

The first screening with the HCA showed differences between situations and revealed a division of samples into two clusters (Figure 2). This analysis groups samples without previous classification according to their similitudes and does not inform which variables cause such classification (Farmaki et al. 2012). Therefore, by considering the soil's conditions (Table 1) within clusters, farming seemed to be the cause driving the clustering structure, linking together in one group situations of soils under zero tillage (RF4, RF5) and another of natural cover condition soil (RF1, RF2, RF3).

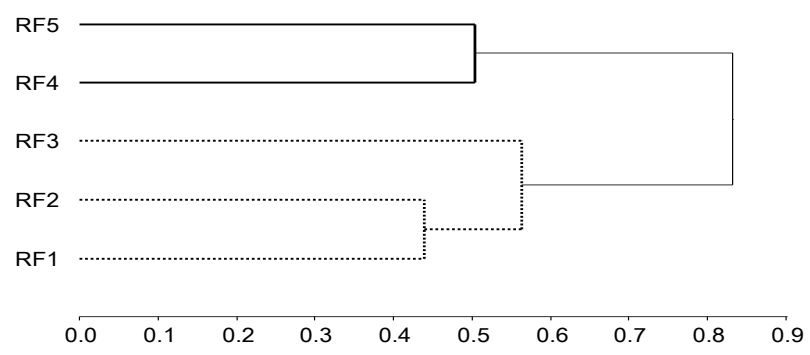

Figure 2: Hierarchical clustering dendrogram from full set of variables. Grouping of samples in two clusters according to tillage: Soils without tillage (dotted line) including grassland without glyphosate application (RF1), grassland after one application of glyphosate (RF2), grassland after two glyphosate applications (RF3); and Soils with zero tillage (bold line) including corn crop monoculture (RF4) and bean - chickpea sequence (RF5) with 5 years of continuous glyphosate application by spraying. Linkage method: average linkage. Distance: Gower $(\operatorname{sqrt}(1-S))$. Cophenetic correlation coefficient $\mathbf{0 . 9 8 8}$.

This classification of samples as cultivated with zero tillage (ZT) and natural cover condition soils (NC) was used as a reference for the discriminant analysis (KNN). Using five different sets of variables upon the previous cluster's classification (Figure 2), the samples only showed similar 
classification to the originally given when physical indicators were considered (Figure 3). Hence, the physical properties overall were stable to perturbations caused by glyphosate application and changes in soil cover vegetation. When the set of chemical indicators was used, there was a misclassification of sample RF2 (collected from natural condition soil after $24 \mathrm{~h}$ of glyphosate application) that located it in the group of soils under zero tillage (Figure 3). Since RF2 originally grouped as $\mathrm{NC}$, allocation on the cluster of ZT could suggest that the chemical properties of the soil acted as good indicators of shortterm perturbation when considering glyphosate application.

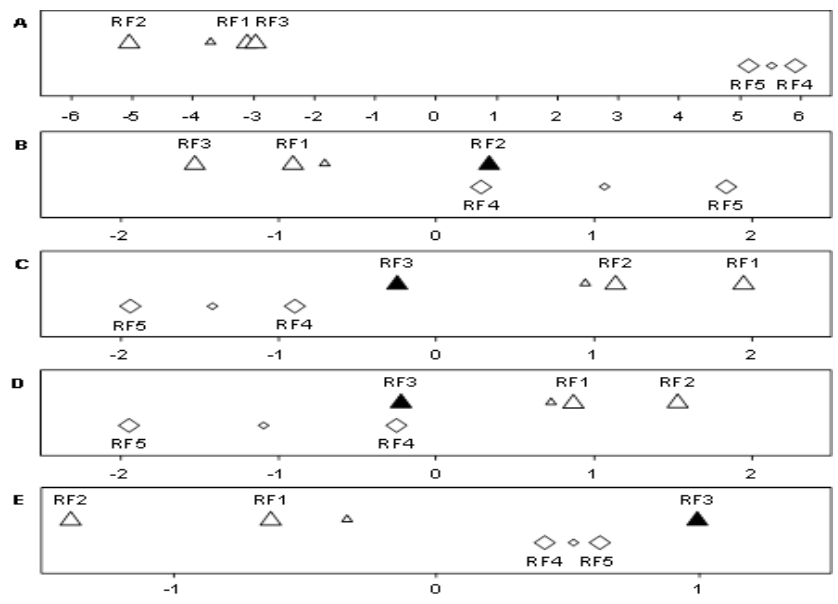

Figure 3: Score plots of discriminant function 1 using different sets of variables: A) Physical indicators (Texture, WSA, AWC, SEC, pH); B) Chemical indicators ( $\mathrm{SN}$, POM, TOC, C/N, SPA, $\mathrm{CO}_{3}$, ESP, EK, ECa, EMg); C) Biological indicators (TAM, MBC, MR, DHA, PMN, qCO); D) PMG and AMPA concentration in the soil; E) complete set of indicators. Triangles represent samples without tilling: grassland without glyphosate application (RF1), grassland after one application of glyphosate (RF2), and grassland after two glyphosate applications (RF3); in diamonds samples with zero tillage: corn crop monoculture (RF4), and bean - chickpea sequence (RF5) with 5 years of continuous glyphosate application by spraying. Figures in black represent misclassified samples, compared to the HCA classification used as reference (in all cases, except $A$, the general classification error was $33.3 \%$ and the sample classification error was $20 \%$ ), and smaller symbols locate the samples group centroid.

Sample RF3, also from the cluster of NC was misclassified as ZT on three occasions, first using the set of biological indicators, second with only the soil's concentrations of glyphosate and AMPA, and third when considering all the indicators determined in this study.
Soil microbial communities are resilient and resistant to stressors that cause diversity decline (Wertz et al. 2007; CruzMartínez et al. 2009). Nevertheless, depending on the nature of the stress, the community can resist an initial perturbation, which lowers its stability leaving it vulnerable against future perturbations (Steenwerth et al. 2005; Kuan et al. 2006). Like so, on sample RF3 (sprayed with glyphosate twice within two months) the biological indicators response evidenced changes of quality in the long term when considering a direct application of the herbicide. Also, whereas RF3 was classified within the ZT cluster, the only difference between it and RF1 and RF2 was a higher exposure to glyphosate. Thence similar error of classification of RF3 when using the indicators of $P M G$ and $A M P A$ on the soil (Figure 3) supported that the change of soil quality evidenced by their presence in the ground is noticeable in the long term. The error of classification of sample RF3 when the complete set of indicators was used showed the strong influence of the soil's biological response to the perturbation caused by the direct spraying with glyphosate over time since both physical and chemical indicators did not discriminate RF3 erroneously.
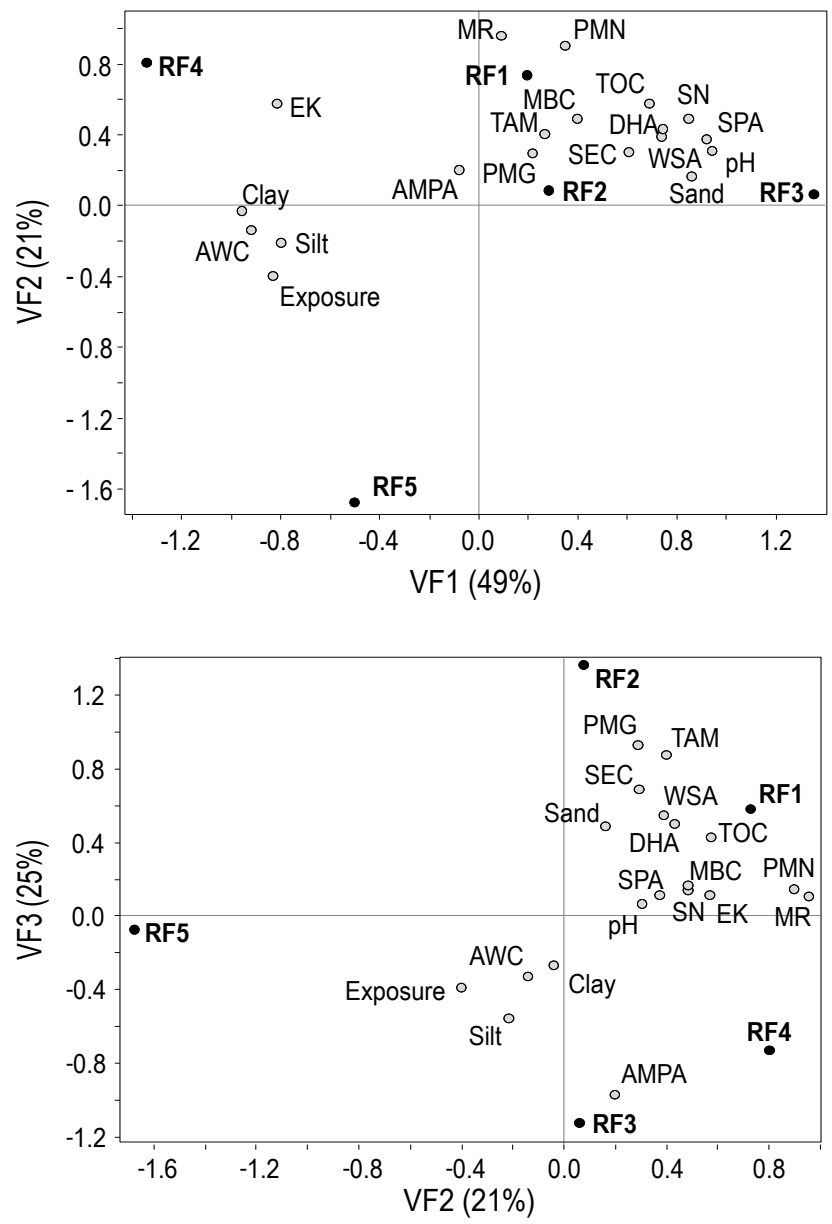

Soil Environ. 36(2): 141-154, 2017 


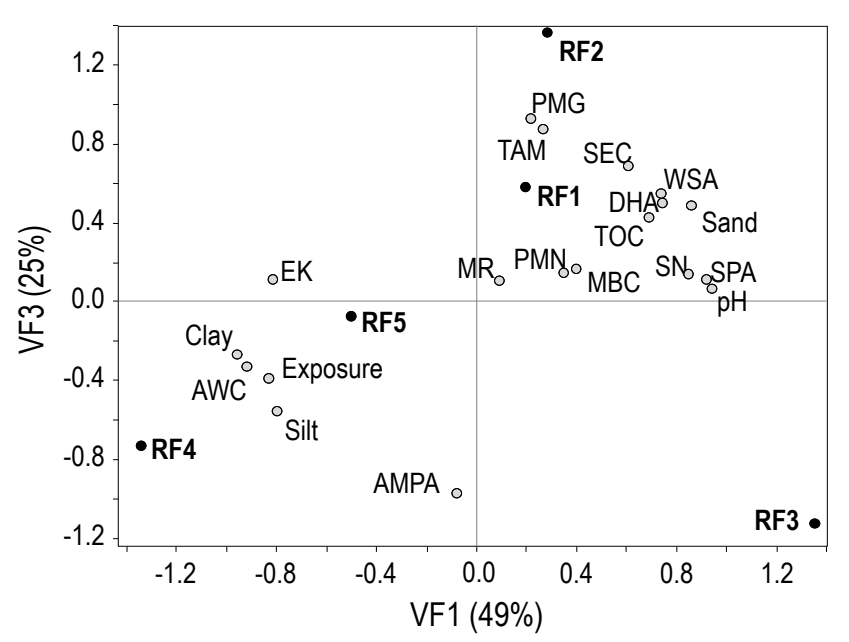

Figure 4: Bi-Plots of varifactors for samples from grassland without glyphosate application (RF1), after one application of glyphosate (RF2), and after two glyphosate applications (RF3), corn crop monoculture (RF4), and bean - chickpea sequence (RF5) with 5 years of continuous glyphosate application by spraying. The samples are represented with the black dots while the variables are represented with the gray dots. AMPA: (Aminomethyl)phosphonic acid soil concentration; AWC: available water capacity; Clay: clay separate percentage; DHA: dehydrogenase activity; EK: exchangeable potassium; Exposure: history of soil exposure to glyphosate; MBC: microbial biomass carbon; MR: microbial respiration; pH: soil pH; PMG: $\mathrm{N}$-(Phosphonomethyl)glycine soil concentration; PMN: potentially mineralizable nitrogen; Sand: sand separate percentage; SEC: soil electrical conductivity; Silt: silt separate percentage; $\mathrm{SN}$ : soil nitrogen; SPA: soil phosphorus availability; TAM: total plate count of aerobic mesophilic microorganisms; TOC: total organic carbon; WSA: water stable aggregates.

\section{Principal component analysis (PCA)}

Three varifactors (VF) explained $95.4 \%$ of the total variance from samples RF1 to RF5 (Table 4). According to the combined loadings from their variables, each VF depicted a particular scene. In general, VF1 described soil samples for their physicochemical characteristics, VF2 represented the microbial activity related to the nutrient source, and VF3 described the concentration of the herbicide glyphosate and its relation with microbial biomass and soil structure (Table 4).

Almost half of the overall variability of the samples was explained by VF1 (49.1\%). Most of the variables with higher loadings within VF1 corresponded to physical properties (Table 4), explaining the strong division of samples along this axis according to the absence or presence of farming (Figure 4). As showed by the discriminant analysis, the physical indicators remained stable, regardless soil spraying and alteration of the surface cover vegetation. Natural condition samples RF1, RF2, and RF3 grouped closely to the biological indicators in the positive values of VF1, indicating a better quality of this samples regarding biological activity (Figure 4). Moreover, all soil biological indicators seemed to correlate closely with each other in one quadrant when considering any varifactor pairing (VF1 to VF2, VF1 to VF3, VF2 to VF3), correlating as well with higher values of TOC, SN, SPA, WSA, Sand and SEC. This high nutrient availability combined with structure's stability and aeration in the soil matrix (Figure 4) enhances microbial activity, indicating better quality of samples from the natural condition soil.

While the loadings of $T O C$ and $E K$ presented a moderate weight on VF2, it was highly influenced by $M R$ and $P M N$. All the variables mentioned presented a direct correlation. The organic matter in the soil not only served as a reservoir of nutrients and water, but it also enhanced the soil's structure, allowing proper aeration and water infiltration by compaction reduction. All of these characteristics provide conditions in the soil environment that improve the development of the microbial community.

The values of $P M G$ and $A M P A$ showed the highest inertia in VF3, manifesting an inverse relationship (Table 4). Also on VF3, microbial DHA and TAM had moderate and strong loadings, respectively, correlating the latter with $P M G$. Samples RF1 and RF2, regarded as those of higher quality among samples (Figure 4) also showed the best values of the biological properties evaluated. These results could be attributed to the fact that $P M G$, as a substrate, has a short-term effect enhancing the microbial activity, which also leads to the metabolic breakdown of glyphosate arising AMPA in the soil (Mañas et al. 2009). However, repeated and time-prolonged applications with glyphosate (as for RF4 and RF5) had an adverse effect on the biological properties of the soil and on the microbial population, leading to lower counts (although maybe remaining more specialized cells regarding the glyphosate degradation, rising $A M P A$ as a consequence). There was a negative impact of AMPA in the soil microbial community as that reported in earthworms (Domínguez et al. 2016) and also in the soil's structure, evidenced by an inverse correlation of AMPA with TAM, DHA, and WSA. Also, the separation of sample RF3 from the group of biological indicators and nutrients, and its closeness to samples with a longer history of application and growing concentrations of AMPA showed a decline in quality as glyphosate application events proceeded. 


\section{Conclusions}

The soil quality was negatively impacted by tillage and also by the application of glyphosate, becoming worse as the history of exposure increased over time. Glyphosate was, to the best of our knowledge, the only herbicide applied. Chemical indicators showed higher sensitivity to short-term impacts ( $24 \mathrm{~h}$ after spraying), while biological indicators were more sensitive to longer-term (two months) alterations. Conversely, most of the soil physical properties analyzed remained stable towards spraying.

Finally, since this was an observational study, not a designed experiment, no cause-effect relationships are implied, only correlations between observed variables. However, these findings provide information to assess the soil health and quality response towards agricultural management, aiding in the future planning to maintain the soil resource sustainably.

\section{Acknowledgements}

This research was part of research project 2070/4 funded by the Consejo de Investigaciones de la Universidad Nacional de Salta (CIUNSa), Argentina. This project was partially supported by NIH Grant \# D43 TW005718 funded by the Fogarty International Center from the University of California at Davis and the National Institute of Health. Neli Romano Armada was the recipient of graduate fellowships from CONICET. The authors would like to thank Laboratorio de Suelos y Agua at INTA Cerrillos for the soil fertility analysis, Dr. Damián Marino at CIMA, Universidad Nacional de La Plata-CONICET for the determination of glyphosate and AMPA concentration in the soil samples, and Dr. Jerold Last for his kind help with the English corrections.

\section{References}

Amrhein, N., J. Schab and H.C. Steinrücken. 1980. The mode of action of the herbicide glyphosate. Naturwissenschaften 67: 356-357.

Anderson, T.H. and K.H. Domsch. 2010. Soil microbial biomass: The eco-physiological approach. Soil Biology and Biochemistry 42: 2039-2043.

Andréa, M.M. de, T.B. Peres, L.C. Luchini, S. Bazarin, S. Papini, M.B. Matallo and V.L.T. Savoy. 2003. Influence of repeated applications of glyphosate on its persistence and soil bioactivity. Pesquisa Agropecuaria Brasileira 38: 1329-1335.

Aparicio, V.C., E. De Gerónimo, D. Marino, J. Primost, P. Carriquiriborde and J.L. Costa. 2013. Environmental fate of glyphosate and aminomethylphosphonic acid in surface waters and soil of agricultural basins. Chemosphere 93: 1866-1873.
Ashworth, M.B., M.J. Walsh, K.C. Flower and S.B. Powles. 2014. Identification of the first glyphosate-resistant wild radish (Raphanus raphanistrum L.) populations. Pest Management Science 70: 1432-1436.

Baird, D.D., R.P. Upchurch, W.B. Homesley and J.E. Franz. 1971. Introduction of a new broad-spectrum post emergence herbicide class with utility for herbaceous perennial weed control. NCWSS Proceedings 26: 64-68.

Balzarini, M.G., L. Gonzalez, M. Tablada, F. Casanoves, J.A. Di Rienzo and C.W. Robledo. 2008. Manual del Usuario. Córdoba, Argentina. Editorial Brujas.

Benachour, N. and G.E. Séralini. 2009. Glyphosate formulations induce apoptosis and necrosis in human umbilical, embryonic, and placental cells. Chemical Research in Toxicology 22: 97-105.

Bouyoucos, G.J. 1962. Hydrometer method improved for making particle size analysis of soils. Agronomy Journal 54: 464-465.

Bray, R.H. and L.T. Kurtz. 1945. Determination of total, organic, and available forms of phosphorus in soils. Soil Science 59: 39-45.

Bremner, J.M. 1960. Determination of nitrogen in soil by the Kjeldahl method. The Journal of Agricultural Science 55: 11-33.

Broadley, M.R., H.C. Bowen, H.L. Cotterill, J.P. Hammond, M.C. Meacham, A. Mead and P.J. White. 2003. Variation in the shoot calcium content of angiosperms. Journal of Experimental Botany 54: 1431-1446.

Casida, L.E.J., D.A. Klein and T. Santoro. 1964. Soil dehydrogenase activity. Soil Science 98: 371-376.

Ciappa, C. and A. Gallo. 2011. p. 71-96. In: The economies of Argentina and Brazil: A comparative perspective. W. Baer and D.V. Fleischer (eds.), The agricultural sector in Argentina. Cheltenham, UK. Edward Elgar Publishing.

Clair, É., R. Mesnage, C. Travert and G.É. Séralini. 2012. A glyphosate-based herbicide induces necrosis and apoptosis in mature rat testicular cells in vitro, and testosterone decrease at lower levels. Toxicology in Vitro 26: 269-279.

Corvalán, E.R., A. Franzoni, D. Huidobro and J.L. Arzeno. 2000. Método de microtamices para la determinación de la estabilidad de agregados del suelo, 1-2 mm. XVII Congreso Argentino de la Ciencia del Suelo.

Cruz-Martínez, K., K.B. Suttle, E.L. Brodie, M.E. Power, G.L. Andersen and J. F. Banfield. 2009. Despite strong seasonal responses, soil microbial consortia are more resilient to long-term changes in rainfall than overlying grassland. The ISME Journal 3: 738-744.

Dill, G.M. 2005. Glyphosate-resistant crops: history, status and future. Pest Management Science 61: 219-224.

Domínguez, A., G. Gardner Brown, K.D. Sautter, C.M. Ribas de Oliveira, E. Carvalho de Vasconcelos, C.C. Niva, M.L.C. Bartz and J.C. Bedano. 2016. Toxicity of 
AMPA to the earthworm Eisenia andrei Bouché, 1972 in tropical artificial soil. Scientific Report 6.

Doran, J.W. 1980. Soil microbial and biochemical changes associated with reduced tillage. Soil Science Society of America Journal 44: 765-771.

Doran, J.W. and T.B. Parkin. 1994. p. 1-21. In: Defining and assessing soil quality. J.W. Doran, D.C. Coleman, D.F. Bezdicek and B.A. Stewart (eds.), Defining Soil Quality for a Sustainable Environment. Madison, Wisconsin, USA. Soil Science Society of America, American Society of Agronomy.

Doran, J.W. and T.B. Parkin. 1996. p. 25-37 In: Methods for assessing soil quality. J.W. Doran and A.J. Jones (eds.), Madison, Wisconsin, USA. SSSA, Inc.

Duke, S.O. and S.B. Powles. 2009. Glyphosate-resistant crops and weeds: Now and in the future. AgBioForum 12: 346-357.

Evans, S.E. and M.D. Wallenstein. 2014. Climate change alters ecological strategies of soil bacteria. Ecology Letters 17: 155-164.

FAO (Food and Agriculture Organization of the United Nations). 2014. FAOSTAT.

Farmaki, E.G., N.S. Thomaidis, V. Simeonov and C.E. Efstathiou. 2012. A comparative chemometric study for water quality expertise of the Athenian water reservoirs. Environmental Monitoring and Assessment 184: 76357652.

Fernández Linares, L.C., N.G. Rojas Avelizapa, T.G. Roldán Carrillo, M.E. Ramírez Islas, H.G. Zegarra Martínez, R. Uribe Hernández, R.J. Reyes Ávila, D. Flores Hernández and J.M. Arce Ortega. 2006. Manual de técnicas de análisis de suelos aplicadas a la remediación de sitios contaminados. Mixcoac. Editorial del Deporte Mexicano.

Fernandez-Cornejo, J., C. Hallahan, R. Nehring, S. Wechsler and A. Grube. 2012. Conservation tillage, herbicide use, and genetically engineered crops in the United States: The case of soybeans. AgBioForum 15: 231-241.

Givens, W.A., D.R. Shaw, G.R. Kruger, W.G. Johnson, S.C. Weller, B.G. Young, R.G. Wilson, M.D.K. Owen and D. Jordan. 2009. Survey of tillage trends following the adoption of glyphosate-resistant crops. Weed Technology 23: 150-155.

Griffiths, B.S., K. Ritz, R.D. Bardgett, R. Cook, S. Christensen, F. Ekelund, S.J. Sørensen, E. Bååth, J. Bloem, P.C. de Ruiter, J. Dolfing and B. Nicolardot. 2000. Ecosystem response of pasture soil communities to fumigation-induced microbial diversity reductions: an examination of the biodiversity-ecosystem function relationship. Oikos 90: 279-294.

Gupta, S.C. and W.E. Larson. 1979. Estimating soil water retention characteristics from particle size distribution, organic matter percent, and bulk density. Water Resources Research 15: 1633-1635.

Haney, R.L., S.A. Senseman, F.M. Hons and D.A. Zuberer. 2000. Effect of glyphosate on soil microbial activity and biomass. Weed science 48: 89-93.

Hermans, M. 2003. Small- and medium-sized enterprises' restructuring in a context of transition: a shared process. Inter-player effects on efficient boundary choice in the Argentine manufacturing sector. Santiago, Chile. United Nations Publication.

Hill, R.L. 1990. Long-term conventional and No-tillage effects on selected soil physical properties. Soil Science Society of America Journal 54: 161-166.

Horn, R., H. Taubner, M. Wuttke and T. Baumgartl. 1994. Soil physical properties related to soil structure. Soil and Tillage Research 30: 187-216.

Imfeld, G. and S. Vuilleumier. 2012. Measuring the effects of pesticides on bacterial communities in soil: A critical review. European Journal of Soil Biology 49: 22-30.

INTA (Instituto Nacional de Tecnología Agropecuaria). 2009. Adecuación a un Sistema de Información Geográfica del estudio "Los Suelos del NOA (Salta y Jujuy), Nadir A. - Chafatinos T., 1990.” Salta, Argentina. Ediciones INTA.

ISO (International Organization for Standardization). 1993. ISO 10381-6. Soil quality, Sampling, Part 6: Guidance on the collection, handling and storage of soil under aerobic conditions for the assessment of microbiological processes, biomass and diversity in the laboratory. Geneva, Switzerland. International Organization for Standardization.

Janniche, G.S., H. Spliid and H.J. Albrechtsen. 2012. Microbial community-level physiological profiles (CLPP) and herbicide mineralization potential in groundwater affected by agricultural land use. Journal of Contaminant Hydrology 140: 45-55.

Kaiser, H.F. 1960. The application of electronic computers to factor analysis. Educational and Psychological Measurement XX: 141-151.

Keeney, D.R. and J.M. Bremner. 1966. Comparison and evaluation of laboratory methods of obtaining an index of soil nitrogen availability. Agronomy Journal 58: 498503.

Kuan, H.L., C. Fenwick, L.A. Glover, B.S. Griffiths and K. Ritz. 2006. Functional resilience of microbial communities from perturbed upland grassland soils to further persistent or transient stresses. Soil Biology and Biochemistry 38: 2300-2306.

Lee, Z.M. and T.M. Schmidt. 2014. Bacterial growth efficiency varies in soils under different land management practices. Soil Biology and Biochemistry 69: 282-290. 
Li, S., X. Jiang, X. Wang and A.L. Wright. 2015. Tillage effects on soil nitrification and the dynamic changes in nitrifying microorganisms in a subtropical rice-based ecosystem: A long-term field study. Soil and Tillage Research 150: 132-138.

Lotter, D. 2014. Facing food insecurity in Africa: Why, after 30 years of work in organic agriculture, I am promoting the use of synthetic fertilizers and herbicides in smallscale staple crop production. Agriculture and Human Values 32: 111-118.

Lupwayi, N.Z., K.N. Harker, G.W. Clayton, J.T. O’Donovan and R.E. Blackshaw. 2009. Soil microbial response to herbicides applied to glyphosate-resistant canola. Agriculture, Ecosystems and Environment 129: 171-176.

Lupwayi, N.Z., K.N. Harker, J.T. O'Donovan, T.K. Turkington, R.E. Blackshaw, L.M. Hall, C.J. Willenborg, Y. Gan, G P. Lafond, W.E. May and C.A. Grant. 2015. Relating soil microbial properties to yields of no-till canola on the Canadian prairies. European Journal of Agronomy 62: 110-119.

Mal, P., P.M. Schmitz and J.W. Hesse. 2015. Economic and environmental effects of conservation tillage with glyphosate use: A case study of Germany. Outlooks on Pest Management 26: 24-28.

Mañas, F., L. Peralta, J. Raviolo, H. García Ovando, A. Weyers, L. Ugnia, M. Gonzalez Cid, I. Larripa and N. Gorla. 2009. Genotoxicity of AMPA, the metabolite of glyphosate, assessed by the Comet assay and cytogenetic tests. Ecotoxicology and Environmental Safety 72: 834837.

Mandiola, M., G.A. Studdert, G.F. Domínguez and C.C. Videla. 2011. Organic matter distribution in aggregate sizes of a mollisol under contrasting managements. Journal of Soil Science and Plant Nutrition 11: 41-57.

Martinez-Salgado, M.M., V. Gutiérrez-Romero, M. Jannsens and R. Ortega-Blu. 2010. Biological soil quality indicators: a review. Pp. 319-328 in A. Mendez-Vilas (ed.), Current Research, Technology and Education Topics in Applied Microbiology and Microbial Biotechnology. Badajoz, Spain. Formatex Research Center.

Micheni, A., D. Mburu, F. Kanampiu, N. Mugai and F. Kihanda. 2014. Glyphosate-based herbicides on weeds management and maize performance under conservation agriculture practices in eastern Kenya. International Journal of Agricultural Resources, Governance and Ecology 10: 257-268.

Modesto, K.A. and C.B.R. Martinez. 2010. Roundup ${ }^{\circledR}$ causes oxidative stress in liver and inhibits acetylcholinesterase in muscle and brain of the fish Prochilodus lineatus. Chemosphere 78: 294-299.

Murphy, G.M., R.H. Hurtado, M.E. Fernández Long, L.A. Serio, P.A. Faroni, S. Maio, L.B. Spescha and I.E.
Barnatán. 2008. Atlas agroclimático de la Argentina. Buenos Aires, Argentina. Editorial Facultad Agronomía.

Nail, E.L., D.L. Young and W.F. Schillinger. 2007. Diesel and glyphosate price changes benefit the economics of conservation tillage versus traditional tillage. Soil and Tillage Research 94: 321-327.

Nandula, V.K., K.N. Reddy, S.O. Duke and D.H. Poston. 2005. Glyphosate-resistant weeds: Current status and future outlook. Outlooks on Pest Management 12: 183187.

Nunes, M.R., J.E. Denardin, E.A. Pauletto, A. Faganello and L.F. Spinelli Pinto. 2015. Mitigation of clayey soil compaction managed under no-tillage. Soil and Tillage Research 148: 119-126.

Owen, M.D.K. 2008. Weed species shifts in glyphosateresistant crops. Pest Management Science 64: 377-387.

Paganelli, A., V. Gnazzo, H. Acosta, S.L. López and A.E. Carrasco. 2010. Glyphosate-based herbicides produce teratogenic effects on vertebrates by impairing retinoic acid signaling. Chemical Research in Toxicology 23: 1586-1595.

Panettieri, M., L. Lazaro, R. López-Garrido, J.M. Murillo and E. Madejón. 2013. Glyphosate effect on soil biochemical properties under conservation tillage. Soil and Tillage Research 133: 16-24.

Paradelo, R., F. van Oort and C. Chenu. 2013. Waterdispersible clay in bare fallow soils after 80 years of continuous fertilizer addition. Geoderma 200: 40-44.

Poletta, G.L., A. Larriera, E. Kleinsorge and M.D. Mudry. 2009. Genotoxicity of the herbicide formulation Roundup ${ }^{\circledR}$ (glyphosate) in broad-snouted caiman (Caiman latirostris) evidenced by the Comet assay and the Micronucleus test. Mutation Research/Genetic Toxicology and Environmental Mutagenesis 672: 95102.

Powles, S.B. 2008. Evolved glyphosate-resistant weeds around the world: lessons to be learnt. Pest Management Science 64: 360-365.

Rahmanipour, F., R. Marzaioli, H.A. Bahrami, Z. Fereidouni and S. R. Bandarabadi. 2014. Assessment of soil quality indices in agricultural lands of Qazvin Province, Iran. Ecological Indicators 40: 19-26.

Ratcliff, A.W., M.D. Busse, and C.J. Shestak. 2006. Changes in microbial community structure following herbicide (glyphosate) additions to forest soils. Applied Soil Ecology 34: 114-124.

Reddy, K.N., W. Ding, R.M. Zablotowicz, S.J. Thomson, Y. Huang and L.J. Krutz. 2010. Biological responses to glyphosate drift from aerial application in nonglyphosate-resistant corn. Pest Management Science 66: 1148-1154. 
Di Rienzo, J.A., F. Casanoves, M.G. Balzarini, L. Gonzalez, M. Tablada and C.W. Robledo. 2014. InfoStat (released version 2014).

Rigby, D. and D. Cáceres. 2001. Organic farming and the sustainability of agricultural systems. Agricultural Systems 68: 21-40.

Rowlings, D.W., P.R. Grace, R. Kiese and K.L. Weier. 2012. Environmental factors controlling temporal and spatial variability in the soil-atmosphere exchange of $\mathrm{CO} 2$, $\mathrm{CH} 4$ and $\mathrm{N} 2 \mathrm{O}$ from an Australian subtropical rainforest. Global Change Biology 18: 726-738.

Service, R.F. 2013. What happens when weed killers stop killing? Science 341: 1329.

Sheehy, J., K. Regina, L. Alakukku and J. Six. 2015. Impact of no-till and reduced tillage on aggregation and aggregate-associated carbon in Northern European agroecosystems. Soil and Tillage Research 150: 107113.

Steenwerth, K.L., L.E. Jackson, F.J. Calderón, K.M. Scow and D.E. Rolston. 2005. Response of microbial community composition and activity in agricultural and grassland soils after a simulated rainfall. Soil Biology and Biochemistry 37: 2249-2262.

Steinrücken, H.C. and N. Amrhein. 1980. The herbicide glyphosate is a potent inhibitor of 5-enolpyruvyl shikimic acid-3-phosphate synthase. Biochemical and Biophysical Research Communications 94: 1207-1212.

USDA (United States Department of Agriculture). 1996. Soil quality information sheet. Indicators for soil quality evaluation. Washington, DC, USA. Natural Resources Conservation Service, U.S. Department of Agriculture.

USDA (United States Department of Agriculture). 2002.Title 430, National soil survey handbook, Part 624 - Soil quality.Natural Resources Conservation Service. online: http://1.usa.gov/1g0qbwW. Accessed 26 April 2016

USDA (United States Department of Agriculture). 2015.Soil health.Natural Resources Conservation Service. online: https://www.nrcs.usda.gov/wps/portal/nrcs/main/soils/he alth/. Accessed 26 April 2016
Vance, E.D., P C. Brookes and D.S. Jenkinson. 1987. An extraction method for measuring soil microbial biomass. Soil Biology and Biochemistry 19: 703-707.

Vargas-Tapia, P., J.Z. Castellanos-Ramos, J. de J. MuñozRamos, P. Sánchez-García, L. Tijerina-Chávez, R.M. López-Romero, C. Martínez-Sánchez and J.L. Ojodeagua-Arredondo. 2008. Efecto del tamaño de partícula sobre algunas propiedades físicas del tezontle de Guanajauto, México. Agricultura técnica en México 34: 323-331.

Vila-Aiub, M.M., R.A. Vidal, M.C. Balbi, P.E. Gundel, F. Trucco, and C.M. Ghersa. 2008. Glyphosate-resistant weeds of South American cropping systems: an overview. Pest Management Science 64: 366-371.

Walkley, A. and I.A. Black. 1934. An examination of the Degtjareff method for determining organic carbon in soils: Effect of variations in digestion conditions and of inorganic soil constituents. Soil Science 63: 251-263.

Wertz, S., V. Degrange, J.I. Prosser, F. Poly, C. Commeaux, N. Guillaumaud and X. Le Roux. 2007. Decline of soil microbial diversity does not influence the resistance and resilience of key soil microbial functional groups following a model disturbance. Environmental Microbiology 9: 2211-2219.

White, P.J. and M.R. Broadley. 2003. Calcium in plants. Annals of Botany 92: 487-511.

Zhao, H. and S. Ram. 2006. Clustering similar schema elements across heterogeneous databases: A first step in database integration. Pp. 227-248 in K. Siau (ed.), Advanced Topics in Database Research. USA. Idea Group Publishing. 